REVISTA DE DERECHO UNED, núm. 3, 2008

\title{
EL TRATAMIENTO DE LOS INTERESES EN EL DERECHO CANÓNICO Y EN EL DERECHO ISLÁMICO
}

\author{
FRANCISCO JAVIER JimÉNEZ MUÑoz ${ }^{1}$
}

Resumen: A partir de la Edad Media se establece en el Derecho canónico una prohibición general de la usura, y por extensión de los intereses, que recibió el apoyo dogmático de los escolásticos, en especial Santo Tomás de Aquino. Paralelamente, sin embargo, se comienza a observar una cierta relajación de la prohibición, debida a la creación de los montes de piedad. Esta prohibición, no obstante, fue reiteradamente inobservada en la práctica, proliferando los medios para eludirla, fundamentalmente por exigencias de la economía bajomedieval. No será hasta el Código de Derecho Canónico de 1917 cuando finalmente se declare la admisibilidad de los intereses. El Derecho islámico, en cambio, sigue manteniendo hoy -al menos nominalmente - una similar prohibición de los intereses (ribā), aunque en él tienen una especial importancia los subterfugios, entre los que destaca la venta doble, que en la Europa medieval terminó influyendo en el denominado contrato de mohatra. Últimamente, sin embargo, a raíz del enorme desarrollo de varios países petroleros árabes, han surgido autores que abogan por una interpretación distinta de la riba $\bar{a}$, de modo que sólo la serían aquellos intereses que supongan una falta de equidad para alguna de las partes, en función de las circunstancias de cada operación particular.

Palabras clave: Intereses, usura. Derecho canónico. Iglesia católica. Escolástica, Santo Tomás de Aquino. Derecho islámico (shari'a). Ribā. Subterfugios (hiyal), mohatra.

\footnotetext{
Profesor Colaborador del Departamento de Derecho Civil de la UNED. Doctor europeo en Derecho.
} 
Abstract: From Middle Ages, it was settled in Canonical Law a general ban of usury, and broadly of interests, with dogmatical support from scholastics, especially St Thomas Aquinas. Parallel, however, at this time it began to be observed some relaxation of the prohibition, due to the creation of savings banks. This banning, however, was repeatedly unobserved in practice, proliferating means to elude it, mainly due to Lower Middle Ages Economy exigencies. It will be with the Canonical Law Code 1917 when at last the admissibility of interests shall be declared.

Islamic Law, by contrast, keeps on upholding today - at least nominally - a similar ban of interests (rib $\bar{a})$, although in it subterfuges are especially important; amongst them it's remarkable the double selling, that in medieval Europe finally had influence on the so called 'contract of mohatra'. Latterly, however, because of the huge growth experienced by some Arab oil countries, they have been arised authors who plead for a different interpretation of riba $\bar{a}$, so that it would only exist in those interests that implicate a lack of equity for any of parties, according to circumstances of the particular transaction.

Keywords: Interests, usury. Canonical Law. Roman Catholic Church. Scholastic, St Thomas Aquinas. Islamic Law (shari'a). Ribā, subterfuges (hiyal), mohatra.

Sumario. I. INTRODUCCIÓN. - II. LA DOCTRINA DE LA IGLESIA CATÓLICA SOBRE LOS INTERESES: EVOLUCIÓN HISTÓRICA. II.1. Fundamento y precedentes de la prohibición canónica de los intereses. La Alta Edad Media. - II.2. La Baja Edad Media y la Edad Moderna. - II.3. La superación de la prohibición canónica de los intereses. - III.- TRATAMIENTO DE LOS INTERESES EN EL DERECHO ISLÁMICO. - III.1. La prohibición de la ribā. - III.2. Las hiyal. En especial, el mohatra. - III.3. La tipología de la ribā a efectos de su prohibición. - III.4. Orientaciones favorables a los intereses. - BIBLIOGRAFÍA.

\section{INTRODUCCIÓN}

En el Derecho romano, las usurae se utilizaban por una parte como precio o remuneración por el uso del capital - y de ahí su denominación- y compensación por el riesgo de insolvencia (sortis periculum) que puede correr el mutuante ${ }^{2}$, fundamentalmente a tra-

${ }^{2}$ Vid. D., XVII, II, 67, 1. 
vés de la figura del foenus o préstamo con intereses, y por otra en determinados casos de reconocimiento de unas usurae legales $^{3}$.

Ello no obstante, los tipos de interés requeridos para determinados préstamos (sobre todo respecto de simientes y especies) llegaron a niveles elevadísimos, lo que motivó que ya desde los primeros tiempos se intentara limitarlos. Tras una oscilación entre prohibición y admisión (aunque limitada) de los intereses, a partir de la Edad Media se establece una prohibición canónica general de la usura y, por extensión, de los intereses, sobre bases religioso-morales, aunque no siempre respetada en la práctica.

Sin embargo, con la Reforma calvinista esa prohibición se fue atenuando paulatinamente hasta desaparecer, sobre todo a partir de la Codificación napoleónica, siendo plasmada la realidad de los intereses en la generalidad de los Códigos actuales. Desde luego, nadie discute hoy la licitud de los intereses, salvo en el ámbito musulmán, donde el Derecho islámico (shari'a) sigue manteniendo hoy -al menos nominalmente - una prohibición de la rib $\bar{a}$ (intereses) similar a la del Derecho canónico medieval.

Es precisamente sobre el tratamiento que reciben los intereses, tanto en el Derecho canónico de la Iglesia católica - ya desde la Alta Edad Media- como en la shari'a, sobre lo que versará el presente estudio.

\section{LA DOCTRINA DE LA IGLESIA CATÓLICA SOBRE LOS INTERESES: EVOLUCIÓN HISTÓRICA}

\section{II.1. FUNDAMENTO Y PRECEDENTES DE LA PROHIBICIÓN CANÓNICA DE LOS INTERESES. LA ALTA EDAD MEDIA}

La prohibición canónica medieval de la usura y, por extensión, de los intereses tenía unas bases religioso-morales.

El Antiguo Testamento prohibía cualquier forma de préstamo con intereses entre los judíos, si bien lo permitía respecto a los ex-

${ }^{3}$ En concreto, en los supuestos de usurae ex mora, usurae a favor del Fisco y otros menos importantes (por uso indebido de dinero, por dejar improductivo el dinero de otro - usurae pro pecunia otiosa - , para restablecer un equilibrio económico alterado por un hecho ilícito, por un especial privilegio reconocido al acreedor o post litem contestatam e rei iudicatae). Cfr. HERRERA BRAvo, Ramón: «Usurae». Problemática jurídica de los intereses en Derecho romano, Ed. Universidad de Jaén, Jaén, 1997, págs. 77-107. 
tranjeros ${ }^{4}$, y en el Evangelio de San Lucas se afirmaba el principio de mutuum date nihil inde sperantes 5 .

Pese a la doctrina construida en contra de la licitud de los intereses, básicamente por los Santos Padres' nicas prohibían el préstamo con intereses sólo a los sacerdotes, y no

${ }^{4}$ Exodo, 22, 24: "Yavé dijo a Moisés: (...) "Si prestas dinero a uno de mi pueblo, a un pobre que habita en medio de vosotros, no te portarás con él como acreedor y no le exigirás usura"»; comillas interiores en el original (en ésta y las siguientes citas bíblicas empleamos la traducción de la Sagrada Biblia de Eloino NÁCAR FUSTER y Alberto CoLunga Cueto, 42. ${ }^{a}$ ed., Biblioteca de Autores Cristianos, La Editorial Católica, Madrid, 1981).

Levítico, 25, 35-37: "Yavé habló a Moisés en el monte Sinaí, diciendo: (...) “Si empobreciere tu hermano y te tendiere su mano, acógele y viva contigo como peregrino y colono; no le darás tu dinero a usura ni de tus bienes a ganancia. Teme a tu Dios y viva contigo tu hermano. No le prestes tu dinero a usura ni tus bienes a ganancia" "; comillas interiores en el original.

Deuteronomio, 23, 19-20: "No exijas de tus hermanos interés alguno, ni por dinero, ni por viveres, ni por nada de lo que con usura suele prestarse. Puedes exigírselo al extranjero, pero no a tu hermano, para que Yavé, tu Dios, te bendiga en todas tus empresas en la tierra en que vas a entrar para poseerla».

Salmo 14, 1. 5: "(..) Yavé, ¿quién es el que puede ser huésped de tu tabernáculo, quién podrá residir en tu monte santo? (...) El que no da a usura su dinero y no admite cohecho para condenar al inocente. Al que tal hace, nadie jamas le hará vacilar".

Ezequiel, 18, 5. 8: «El que sea justo y haga juicio y justicia (...) no dé a logro ni reciba a usura, retraiga su mano del mal y haga juicio de verdad entre hombre y hombre".

Ezequiel, 18, 1. 13: "Fueme dirigida la palabra de Yavé, diciendo: (...) dé a logro y reciba a usura, ¿vivirá éste? No vivirá. Hizo todas esas abominaciones, de cierto morirá. Recaerá su sangre sobre él».

Ezequiel, 22, 12: "Hay en ti quien recibe dones para derramar sangre; exiges usura e intereses, despojas con violencia al prójimo, y a mí me olvidas, dice el Señor, Yavé».

Por otra parte, en el Talmud, el Babá Metziá declara nulo el préstamo con intereses («en el caso de préstamo a interés, el crédito es nulo. Están considerados como cómplices el escribano que hace el acta y el fiador»), el Babá Camá establece que «el usurero es parecido al criminal, ya que el mal que uno y otro producen es irreparable" y el Libro del Sanedrín prohíbe a los usureros ser testigos ante la justicia (cfr. PUIG PEÑA, Federico: «Interés del dinero», NEJ, T. XIII, Ed. Francisco Seix, Barcelona, 1968, pág. 217).

${ }^{5}$ Lucas, 6, 34-35: "Si prestáis a aquellos de quienes esperáis recibir, ¿qué gracia tendréis? También los pecadores prestan a los pecadores para recibir de ellos igual favor. Pero amad a vuestros enemigos, haced bien y prestad sin esperar nada [mutuum date, nihil inde sperantes l, y será mucha vuestra recompensa, pues seréis hijos del Altísimo, porque Él es bondadoso para con los ingratos y malos».

En cambio, se admiten implícitamente los intereses en la parábola de los talentos, en Mateo, 25, 27 («Debias, pues, haber entregado mi denario a los banqueros, para que a mi vuelta recibiese lo mío con los intereses»), e incluso en el propio Lucas, en 19, 23 ("¿por qué, pues, no diste mi dinero al banquero, y yo, al volver, lo hubiera recibido con los intereses?»).

6 Destacadamente los Santos Clemente Alejandrino, Gregorio Nacianceno, Basilio, Juan Crisóstomo, Ambrosio y Jerónimo. 
porque fuera contrario a los principios cristianos, sino porque no era conforme al estado eclesiástico. Así, en el mismo año 325 del Concilio ecuménico de Nicea ${ }^{7}$, Constantino dictaba una Constitución que consideraba lícitas las usurae centesimae sobre el dinero y del $50 \%$ sobre las especies.

Sin embargo, en los siglos siguientes se va produciendo un cada vez más restrictivo tratamiento de las usurae. Así, en el 440 el Papa LEón MAGNo, en una carta a los obispos de Campania, Piceno y Toscana, condenaba a los laicos cristianos que practicaban los préstamos a interés. No obstante, el Concilio de Taragena de 516 se limitó todavía a reiterar la prohibición a los canónigos, precisando que la misma regía también cuando se producía a través de géneros o mercancías, cuyo valor debía ser calculado conforme a los precios de mercado.

7 Que prohibía a los canónigos prestar a interés y ordenaba que quien lo hiciese fuese depuesto y desposeído de cánones (can. XVII: "Quoniam multi qui in canone recenfentur, plura habendi studium et turpe lucrum persequentes, divinae scripturae obliti sunt, quae dicit: Argentum suum non dedit ad usuram; et foenerantes, centesimas exiguunt; alquum censuit sancta et magna synodus, ut si quis inventus fuerit post statutum usuras ex mutuo sumere, vel eam rem aliter persequi, vel sesquialteras exigere, vel aliquid aliud excogitare turpis quaestus gratia, e clero deponatur, et sit alienus a canone"). Anteriormente ya se habían pronunciado en contra de la realización de préstamos con usurae, especialmente por parte de los clérigos, los Concilios de Elvira de 305 (can. $\mathrm{XX}$, que ya preveía la posibilidad de excomulgar a clérigos y laicos que practicaran la usura) y I de Arlés de 314 (can. XII: «De ministris qui fenerant, placuit eos juxta formam divinam datam a communione abstineris). Con posterioridad al de Nicea, pueden citarse los Concilios I de Cartago de 348 (can. XIII, Ut non liceat clericis foenerari: "Abundantius episcopus Adrumentinus dixit: In nostro concilio statutum est ut non liceat clericis foenerari. Quod si et sanctitati tuae et huic concilio videatur, praesenti placito designetur. Gratus episcopus dixit: Novellae suggestiones, quae vel obscurae sunt, vel sub genere latent, inspectae a nobis, formam accipient. Ceterum, de quibus apertissime divina scriptura sanxit, non differenda sententia est, sed potius exequenda. Proinde quod in laicis reprehenditur, id multo magis in clericis oportet praedamnari. Universi dixerunt: Nemo contra prophetas, nemo contra evangelia facit sine periculo»), Laodicea de 366 (can. V: "Non licere foenerari ministris altaris, vel in Sacerdotali ordine constitutis, vel usuras vel lucra, quae sexcupla dicuntur, acciperen), Hipona de 393 (can. XXIV, que reproduce el can. XIII del I Concilio de Cartago), III de Cartago de 397 (can. XVI, Ut clerici non sint usurarii: «Ut nullus clericorum amplius recipiat, quam cuiquam accomodaverit: Si pecuniam accipiat, speciem eamdem, quantam dederit, accipiat: et quidquid aliud, tantum, quantum dederit, accipiat»), IV de Cartago de 398 (can. LXVII: «Seditionarios numquam ordinandos clericos, sicut nec usurarius, nec injuriarum suarum ultores") y II de Arlés de 452 (can. XIV, Nec clericus usuras accipiat: «Si quis clericus pecuniam dederit ad usuram, aut conductor alienae rei voluerit esse, aut turpis lucri gratia aliquod negotiationis exercuerit, depositus a communione alienus fiat»). 
La prohibición plena y general a todos de dar préstamos con usura será apuntada en varios concilios parciales ${ }^{8}$ normas particulares 9 . Pero finalmente será a partir del siglo XII cuando se instaure, con los Concilios II y III de Letrán de $1139^{10}$ y $1179^{11}$ respectivamente, Lión de $1180^{12}$, y IV de Letrán de $1215^{13}$, que terminaron plasmándose en las Decretales de GREgoRIo IX (1234) ${ }^{14}$, así como los de Viena de $1311^{15}$ y -bastante después- el propio de Trento ${ }^{16}$. Como vemos,

${ }^{8}$ Como los de Constanza de 814, París de 829 y Ticino de 850.

9 Así, una Capitular de INOCENCIO II (789) establecía que «omnia omnibus interdictum est ad usuram aliquid dare».

${ }^{10}$ Que prohíbe el lucro en el préstamo de cosas fungibles infructíferas, sin trabajo, gasto ni peligro para el prestamista, y generaliza la condena, excomulgando a los usureros manifiestos y declarándoles privados de la posibilidad de hacer válido testamento y recibir sepultura eclesiástica (cap. III, $D$. de usur., V, 19). Asimismo, el can. XIII de este Concilio dispone que "Porro detestabilem et probrosam Divinis et humanis legibus per Scripturam in Veteri et in Novo Testamento abdicatam, illam, in quam, insatiabilem foeneratorum rapacitatem damnatus, et ab omni ecclesiastica consolatione sequestramos, praecipientes, ut nullus archiepiscopus, nullus episcopus vel cujuslibet ordinis abbas seu quivis in ordine et clero nisi cum summa cautela, usurarios recipere praesumat, sed in tota vita infames habeantur et, nisi resipuerint, Cristiana sepultura priventur».

${ }_{11}$ Que en su can. XXV reprodujo la sanción de privación de cristiana sepultura: "Quia in omnibus fere locis tantum usurarum ita inolevit invaluit, ut multi aliis negotiis praetermissis, quasi licet usuras excerceant, et qualiter utriusque testamenti pagina condemnentur, nequaquam attendant: ideo constituimus, ut usurarii manifesti nec ad communionem admittantur altaris, nec Christianam, si in hoc peccato decesserint, accipiant sepulturam. Sed nec eorum oblationem quisquam accipiat. Qui autem acceperit, aut eos Christianae tradiderit sepulturae; et ea quae acceperit, reddere compellatur; et donec ad arbitrium sui episcopi satisfaciat, ab officii sui maneat executione suspensus».

12 Que amenaza con interdicción a las corporaciones y ciudades que dieran protección y hospitalidad a los usureros.

${ }^{13}$ Que prohíbe a los cristianos andar en comercio con aquellos que les agobiaban con usuras inmoderadas (cap. LXVII).

${ }_{14}$ Que recogen asimismo diecinueve decretos sobre esta materia, de los Papas Alejandro III, Urbano III, InOcencio III y Gregorio IX, en el Libro V, Tít. XIX, De usuris.

15 Que sanciona definitivamente la prohibición de dar dinero a interés, declarando nulos los estatutos municipales que permitieran el préstamo con intereses y amenazando con la excomunión a las autoridades civiles y judiciales que los aplicaran, así como declarando - ante la afirmación por los cátaros de la licitud de la usura- que se castigaran como herejes todos los que mantuvieran que la usura no era pecado ("Si quis in illum errorem inciderit, ut pertinaciter affirmare praesumat, exercere usuras, non esse peccatum, decernimus eum, velut haereticum puniendum, locorum vero ordinariis et haereticae pravitatis inquisitoribus districtius injungentes ut contra eos quos de errore hujusmodi diffamatos invenerint aut suspectos, tanquam contra diffamatos, vel suspectos de haeresi proceder non omittant": Clem., de usur., V, 5).

${ }_{16}$ En España, se pronuncian en la misma orientación los Concilios de León de 1267 (tít. De usuris: "Otrosi mandamos que los clérigos e los leigos quo resciben algunas cosas en pennos, que los fructos, en los prodes que se ende levantaron, que los cuenten en aquello por que yaz en pennos. Et si lo non fecier, sera tovido por usurero. Et man- 
primero se prohibió el préstamo con intereses a los clérigos, bajo pena de suspensión de todo oficio y beneficios eclesiásticos, y después se extendió la prohibición a los laicos, bajo pena de excomunión, declarándose además infames e indignos de la Eucaristía y de sepultura eclesiástica a los usureros manifiestos (si bien habría que leer aquí «prestamistas», en general) y calificando de hereje a quien pertinazmente afirmara no ser pecado el ejercicio de la usura.

En el ámbito civil, después de que la Lex romana Wisigothorum y la Lex romana Burgundiorum habían admitido el préstamo con intereses, se asiste en el siglo IX a un alineamiento con la doctrina de la Iglesia. Así, es con CARLOMAGNo, en la Admonitio Generalis del 789 y el Capitular de Nimega del 806, cuando se observan las primeras prohibiciones civiles del préstamo con intereses también a los laicos, y su nieto LOTARIO, en el Capitular de Olona del 825, confirió a los obispos el poder de investigar y castigar con las penas de reprensión y reclusión a aquéllos que practicaran la usura, e impuso a las autoridades civiles la obligación de ayudar a los obispos en tales actividades.

\section{II.2. LA BAJA EDAD MEDIA Y LA EDAD MODERNA}

A partir del siglo XI, el comercio experimentó un importante desarrollo, y de modo paralelo al regreso a la circulación de productos se volvió también a la circulación de la moneda, cuyo uso había sido abandonado prácticamente a favor del trueque. De este modo, el mercado de préstamos comenzó a asumir una configuración moderna, en el sentido de que junto a un crédito al consumo se fue afianzando progresivamente un verdadero mercado financiero para sostener las necesidades de financiación que requerían las nuevas iniciativas comerciales.

\footnotetext{
damos á los clérigos que esta cosa de los pennores que las digan en la Eglesias é las grandes fiestas»), Tarragona de 1291 (que ordena la nulidad de la escritura de venta fraudulenta o con usuras, en el can. XVIII: «Item, statuimus quod si instrumentum venditionis factum fuerit in fraudem vel usuram, tamquam inane et irritum habeatur, et contractus usurarius censeatur») y Salamanca de 1335 (can. XIV, De usuris: "Quoniam nonnulli avaritiae causa turpia lucra sectantes, obliti divini praecepti, quo dictum est: 'Qui pecuniam suma non dedit ad usuram', impelli publice in usurarum voraginem non verentur, non attendentes, quoniam usurarum crimen utriusque Testamenti pagina detestatur, statuit hoc Sanctum Concilium, omnes et cingulos qui de cetero manifeste usuras exercuerint, ipso ipso excommunicationis sententiae subjacere. Ac sub obtestatione divini judicii praelatos teneri ad faciendum eosdem usurarios manifestos publice nunciari excommunicatos per suas dioceses diebus Dominicis et festis»; las comillas interiores son del original).
} 
Sin embargo, como vimos, la prohibición canónica de los intereses se mantenía e incluso se acentuaba, y en esa línea los escolásticos buscaron poner de manifiesto toda forma de usura indirecta, ocupándose juristas y moralistas sobre el problema del justo precio. Paralelamente, se entiende que, aun siendo la usura reprobable y prohibida, no era posible ni aun a menudo conveniente su erradicación total, con lo que se llega a una práctica tolerancia pese a su radical prohibición, lo que viene a expresarse con una muy gráfica comparación del momento: se asimila la usura a la prostitución, de modo que "convendrá, según se dice, que se mantenga la prohibición de principio, aunque ello sea a costa de una cierta tolerancia de hecho» ${ }^{17}$.

La doctrina aristotélica, retomada por las construcciones tomistas, declaraba los intereses contra natura, porque «el dinero es estéril, y no genera dinero" (pecunia pecuniam non parit, o nummus nummum non parit $)^{18}$, a lo que había que añadir la doctrina del iustum

${ }^{17}$ Cfr. Clavero, Bartolomé: Usura. Del uso económico de la religión en la historia, Ed. Tecnos, Madrid, 1984, pág. 41, y los textos que cita en la pág. 52, nota 16.

18 «Muy razonablemente es aborrecida la usura, porque, en ella, la ganancia procede del mismo dinero, y no de aquello para lo que éste se inventó. Pues se hizo para el cambio; y el interés, al contrario, por sí solo produce más dinero. De ahí que haya recibido ese nombre, pues lo engendrado es de la misma naturaleza que sus generadores, y el interés es dinero de dinero; de modo que de todos los negocios éste es el más antinatural» (ARISTÓTEles: Politica, I, X, 1258 b, 4-5, según la ed. de la Biblioteca Básica Gredos, trad. y notas de Manuela García ValdÉs, Madrid, 2000, pág. 32; las negritas son nuestras).

A pesar de su extensión, no podemos dejar de señalar la humorística crítica de Joaquín ESCRICHE [ «Interés c)», en Diccionario razonado de legislación y jurisprudencia, T. III, ed. de Juan B. Guim según la de 1874, Ed. Temis, Bogotá, 1977, págs. 152-153] a la posición aristotélica: "(...) aquel gran filósofo pagano que por tantos siglos ha ejercido un imperio despótico en el mundo cristiano [se refiere, claro es, a ARISTóTELEs], a pesar del trabajo que se tomó para aclarar la cuestión de la generación [del dinero] no pudo nunca llegar a descubrir en ninguna de las muchas piezas de moneda que entraron en su bolsillo algún órgano particular que la hiciese propia para engendrar o producir otra moneda, y se aventuró por fin a sentar como resultado de sus observaciones que el dinero no pare dinero, pecunia non parit pecuniam. Al oír el mundo sorprendido tan importante descubrimiento, proclamó con entusiasmo la nueva verdad: el dinero es estéril, gritaron los filósofos; el dinero es estéril, repitió la muchedumbre; pues si el dinero es estéril, concluyeron todos, es una injusticia exigir interés o ganancia por prestarlo. Del mismo modo y con la misma razón podian haber gritado aquellos sabios y aquellos ignorantes que los edificios son estériles, que lo son las naves, y que lo son las mulas y los machos, pues que ni las mulas ni los machos producen otros machos ni otras mulas, ni las naves otras naves, ni los edificios otros edificios; $y$ haber concluido por lo tanto que todas estas cosas y otras semejantes deben prestarse o arrendarse de balde. Motivo hay para dudar si ARISTOTELES y sus sectarios hablaron de buena fe sobre este asunto, pues que después de haber reconocido que el dinero era estéril, no por eso dejaron de co- 
pretium de SANTO TOMÁs: dado que el dinero era naturalmente improductivo y, por tanto, así debía serlo también en el tráfico mercantil, percibir intereses en los préstamos y créditos era por principio ilícito y contra natura, y por lo tanto contrario al Derecho natural; toda adquisición de dinero sin "verdadero trabajo» es pecaminosa o por lo menos sospechosa; en todas partes debía tenderse a establecer un "justo precio", y hacer lo contrario es pecado ${ }^{19}$.

Ya que en las cosas consumibles el uso no puede separarse de la propia res, SANTO TOMÁs entendía que prestar dinero con intereses es como cobrar dos veces la cosa vendida, y que resulta un contrasentido decir que una cosa consumible (dinero) pueda producir frutos (intereses) ${ }^{20}$. Igualmente, afirma que «recibir intereses por un préstamo monetario es injusto en sí mismo, porque implica la venta de lo que no existe [más adelante dirá «el uso propio y principal del dinero es su consumo o inversión, puesto que se gasta en las transacciones", de modo que deja de existir], con lo que manifiestamente se produce una desigualdad que es contraria a la justicia" "21, y ello tanto si los intereses son en dinero o en otra especie, pues «también todo el que por pacto tácito o expreso recibiere cualquier beneficio cuyo valor pueda ser estimado en dinero incurre en semejante pecado. (...) En cambio, sí es lícito

rrer y afanarse tras él como tras la cosa más fecunda que había en el mundo; mas si en efecto procedía seriamente en la proclamación de su famosa máxima, es muy de extrañar que no se ofreciese a su talento y penetración que aunque una moneda fuese tan incapaz de engendrar otra moneda como de engendrar un morueco o una oveja, podría un hombre sin embargo con una moneda prestada comprar un morueco y dos ovejas que al cabo de un año le produjesen naturalmente dos o tres corderos, de manera que vendiendo este hombre al fin de dicho término su morueco y sus dos ovejas para devolver la moneda al prestamista, y dándole además uno de los corderos por el uso de la suma, debia encontrarse todavia con dos corderos o a lo menos con uno más de riqueza que no hubiera tenido sin el préstamo" (las redondas se corresponden con cursivas del original; las versales son del original).

19 En cambio, San ANTONIO DE FloRenCIA (1389-1450) distinguía entre el préstamo y los negocios que permitían al deudor obtener un lucro con el dinero recibido, admitiéndose en éstos la licitud de los intereses, por la vía de considerarlos distintos del préstamo propiamente dicho y por tanto fuera de la prohibición canónica. Con ello se dejaba una vía para obtener financiación para las operaciones del cada vez más desarrollado comercio. Vid. AsCARELLI, Tullio: Comentario a los artículos 1.282 a 1.284, en Obbligazioni pecuniarie, del Commentario del codice civile de Antonio ScIaloja y Giuseppe Branca, Libro quarto. Delle obbligazioni (art. 1.277-1.284), Ed. Zanichelli-Il Foro Italiano, Bolonia-Roma, 1959, pág. 579.

20 SANTo Tomás de Aouino: Summa Theologica, II-II, q. 78, art. 1 [según la edición: Suma de Teología, T. III -Parte II-II (a)-, Biblioteca de Autores Cristianos, Madrid, 1990, pág. 601]; y Espos. Decalogi, VII, 4.

21 Santo Tomás de Aquino: Summa Theologica, op. cit. (según la ed.: Suma..., op. cit., pág. 601); las negritas son nuestras. 
exigir, en compensación por un préstamo, aquellas cosas que no se miden, como son la benevolencia, la amistad de aquel a quien se prestó $u$ otras semejantes ${ }^{22}$.

No obstante, consideraba lícita la indemnización del damnum emergens y del lucrum cessans. Así, el prestamista puede pactar la compensación del daño que le cause prestar su dinero (damnum emergens), pues nadie está obligado a hacer a otro un beneficio con daño propio ${ }^{23}$, y en cuanto al lucrum cessans debe resarcirse también al prestamista, según la condición de las personas y de los nego$\operatorname{cios}^{24}$, porque si bien todavía no posee en el acto lo que está camino de adquirir, lo tiene sin embargo virtualmente o en potencia ${ }^{25}$. Con ello, se justificaban los intereses moratorios.

Básicamente, la doctrina contraria a la licitud de los intereses se fundamentaba sobre tres argumentos, además de los de base bíblica: la esterilidad del dinero, la igualdad del valor de las prestaciones que debe haber entre las partes en todo contrato y que la propiedad del dinero prestado pasa del prestamista al prestatario ${ }^{26}$.

$\mathrm{Al}$ argumento de la esterilidad del dinero (pecunia pecuniam non parit), que ya hemos visto, se ha opuesto que el préstamo no sería en el fondo más que un alquiler del dinero, y nadie ha señalado una ilicitud del arrendamiento de joyas o muebles o cualquier otra cosa, cuando son (salvo las propiedades territoriales y animales, y éstos no todos) tan estériles como el dinero; que se acepta el censo, que no sería más que un préstamo con intereses asegurado con una finca; que el dinero es el equivalente a mercaderías y efectos estériles, pero también a tierras, que producen renta; que con la inversión del dinero se obtienen beneficios; y que si el dinero no produce frutos naturales sí los produce civiles.

El segundo argumento es el del equilibrio de prestaciones entre las partes que la equidad exige en todo contrato no gratuito. En el préstamo, se dice, restituyendo el prestatario la cantidad que le dio el

22 Summa Theologica, II-II, q. 78, art. 1 (según la ed.: Suma..., op. cit., pág. 604).

${ }^{23}$ Summa Theologica, III-II, q. 78, art. 2, ad. 1 (según la ed.: Suma..., op. cit., pág. 604).

${ }^{24}$ Por ello, cabía entender que en los préstamos a comerciantes o artesanos el prestamista compartía en cierta medida el «riesgo empresarial» y podía legítimamente pedir una parte del beneficio que aquéllos obtuvieran (así, se admitía por contraposición al abuso una honesta utilitas).

${ }_{25}$ Summa Theologica, II-II, q. 62, art. 4 (según la ed.: Suma..., op. cit., pág. 519).

${ }^{26}$ Para una más amplia exposición de estos argumentos y la crítica a los mismos, vid. EsCRICHE: «Interés c)», op. cit., págs. 158-161. 
prestamista devuelve el equivalente exacto de lo recibido, mientras que si el prestamista exigiera alguna cantidad además de la prestada reclamaría más de lo que ha dado, y no serían iguales los valores recíprocamente entregados por las partes. A esto se ha respondido que si bien ello es cierto en el momento del contrato, posteriormente ha de tenerse en cuenta que el prestamista da dinero a cambio de una promesa de restitución a cierto plazo, y ambas no son equivalentes, pues hay una diferencia de utilidad entre una suma de dinero actual y otra a recibir en el futuro. De esta forma, una parte recibe menos que la otra, y esa diferencia ha de ser compensada mediante un aumento sobre la cantidad prestada proporcional al tiempo que la ha tenido el prestatario, aumento constituido por los intereses.

Finalmente, se aduce en contra de la licitud de los intereses que la propiedad del dinero prestado pasa en el momento del préstamo del prestamista al prestatario. Como sería contrario al Derecho natural el que uno reciba frutos de una cosa ajena, se dice, pues por naturaleza los frutos de una cosa pertenecerían al dueño de la misma, si el prestamista recibiese intereses estaría percibiendo frutos de una cosa ajena, de lo que se concluye que los intereses serían contrarios al Derecho natural. Se ha objetado a este argumento que el prestatario se haría dueño del dinero física y materialmente considerado, pero no de su valor, que no se le ha confiado más que por un tiempo determinado y con la obligación de devolverlo a su transcurso. Por otra parte, es del prestamista de quien el prestatario obtiene la propiedad del dinero, y puede entenderse que esa cesión se hace con el pacto de que el prestatario ha de darle parte de los frutos civiles (intereses) que produzca el dinero prestado, estando su propiedad sometida a ese pacto. No debe pagarse por el uso de una cosa cuando ya se tiene su propiedad, pero puede haberse determinado su precio tomando en consideración el uso inherente a la misma ${ }^{27}$.

No obstante, en esta época se comienza a observar paralelamente una cierta relajación de la prohibición, debida a la creación de los montes de piedad. Los tipos de interés, ya originariamente elevados, aumentaron aún más en los siglos XIV y XV, debido a la dificultad de

${ }^{27}$ Por otra parte, cabe asimismo hacerle la objeción de la endeblez del fundamento de esta objeción, pues el hecho de que uno perciba frutos de una cosa ajena no sólo no sería contrario al Derecho natural, sino que sería constitutivo de una de las figuras jurídicas de mayor importancia, el usufructo, de honda raigambre ya desde el Derecho romano (e incluso antes). Así, PaUlo lo definía como «ius alienis rebus utendi fruendi salva rerum substantia» (D., VII, I, 1; las negritas son nuestras). Sobre el usus fructus en el Derecho romano, vid. por todos FuentesEcA, Pablo: Derecho privado romano, ed. del autor, Madrid, 1978, págs. 145-149. 
realización de las prendas por la depresión económica. Ante esta situación, se intentó establecer unas instituciones de crédito sobre prendas que, si bien no siempre con un fin benéfico, aliviasen la presión crediticia, y en tal sentido los franciscanos crearon los primeros montes de piedad en Italia, a los que se les permitió la percepción de intereses con los límites de la cobertura de los gastos de gestión de la propia entidad, lo que se concretaba en unos tipos variables entre el 4 y el $6 \%$, aunque en algunos casos se llegaba al 10\%. El reconocimiento de los montes de piedad se hizo finalmente por la Bula Inter Multiplices, por la que LEÓN X - pese a las muchas oposiciones de algunos sectores (destacadamente los dominicos) a legitimar cualquier tipo de préstamo con intereses- aprobó estas instituciones en el V Concilio de Letrán (1515), considerando que, a la vez que reducían la usura, la carga de sus préstamos venía a representar sólo el equivalente de los gastos por la actuación y mantenimiento de la institución ${ }^{28}$.

Posteriormente, la doctrina general de la Iglesia sobre los intereses será reafirmada (aunque ya con ciertas atenuaciones) por BENEDICTO XIV en la Encíclica Vix pervenit, de 1 de noviembre de 1745, en la que se recogía y aprobaba lo acordado en la junta de cardenales, teólogos y canonistas reunida el 18 de julio y 1 de agosto de aquel año ${ }^{29}$. Se afirmaba la ilicitud de la pretensión de intereses sobre el mutuo por ser contraria a la naturaleza del contrato, con la excepción de la concurrencia de los denominados en la práctica forense del momento «requisitos del Castrense ${ }^{30}$, que podían asimismo invocarse para hacer fructífera una deuda cierta y líquida que llegara a su venci-

${ }^{28}$ Aunque sin dejar de recordar la doctrina canónica de prohibición de la usura: «Dominus noster, Luca Evangelista attestante, aperto nos praecepto obstrinxit, ne ex dato mutuo quidquam ultra sortem sperare debeamus; ea enim est propria usurarum interpretatio, quando videlicet ex usu rei, quae non germinat, nullo labore, nullo sumptu, nullove periculo, lucrum foenusque conquiri studetur" (c. sub Leone $X$, sess. 10).

${ }^{29}$ Las declaraciones de la junta, recogidas en la Encíclica, así como las prevenciones del Papa en su comunicación a los patriarcas, arzobispos, obispos y ordinarios de Italia, se recogen en Escriche: «Interés c)», op. cit., págs. 162-163; y VALLÉs Y PUJALS, J.: Del préstamo a interés, de la usura y de la hipoteca, Librería Bosch, Barcelona, 1933, págs. 60-61.

30 Circunstancias especiales con cuya concurrencia se entendían lícitos los intereses, por considerarse extrínsecos a las propias prestaciones del mutuo, y a las que nos referiremos más adelante en el texto. La construcción de esta doctrina es obra del jurisconsulto del siglo XV Pablo de CASTRo (conocido por el Castrense) sobre la base de la doctrina tomista: la oportunidad efectiva del mutuante de emplear su dinero de otro modo y que por la falta de disponibilidad de la suma prestada el mutuante experimentara un lucrum cessans, de modo que perdiera la ocasión de emplearla ventajosamente, o bien un damnum emergens, sufriendo un daño que habría podido evitar si la suma hubiera permanecido a su disposición. 
miento, para aumentar el tipo de interés y para conseguir el resarcimiento del daño producido por la mora del deudor ${ }^{31}$.

Así, en esta época se consideró al préstamo como contrato esencialmente gratuito, contemplándose el préstamo con intereses como contrato ilícito, de modo que la Rota romana declaró las usurae prohibidas «de iure naturali, Mosaico, evangelico, canonico et civili» ${ }^{32}$.

En el ámbito del Derecho civil, los principios canónicos inicialmente no fueron acogidos. Así, la glosa de Accursio, interpretando los textos justinianeos, invoca la autoridad de IMERIO y BULSAN para demostrar la licitud de las usurae contractuales. Sin embargo, ya BáRTOLO y posteriormente BALDO acogieron las posiciones del Derecho canónico ${ }^{33}$, y pronto también las normas civiles reconocieron la eficacia de la prohibición canónica ${ }^{34}$.

31 Vid. § 1.619 del Regulamentum Gregorianum. En el mismo sentido se volverá a pronunciar el propio BENEDICTO XIV en De Sínodo dioecesana (cit. por Coví́N, Víctor: "Préstamo", EJE, T. XXV, pág. 518): «Siempre ha sido, y es aún la doctrina de la Iglesia Católica, establecida en virtud del acuerdo unánime de todos los Concilios, de los Padres $y$ de los teólogos, que todo provecho sacado del préstamo, es decir, según el lenguaje de la Escuela, sin que el prestamista tenga el título de lucro cesante y de daño emergente, $\dot{u}$ otro título extrinseco al préstamo, es usurario y prohibido por el Derecho natural, divino ó eclesiástico».

32 Así, Recent., párs. III, dec. 660, n. ${ }^{\circ} 3$; párs. IV, T. III, dec. 607, n. $^{\circ} 58$; párs. XVI, dec. 139, n. $^{\circ} 37$, y dec. 401, n. $^{\circ} 31$. En especial en párs. V, T. I, dec. 301 , núms. 31 ss.: "Toto autem Coelo allucinantur Haebraei, dum putant impiam eorum usurarum exactionem a Christianis posse tueri ex Deuteronom. C. XXIII, ibi, non foenerabis fratri tuo sed alieno: et sic ex lege Moysis Deus sibi ipsis indulsisse foenerari caeteris: nam pro obiecti resolutione praemonendi sunt usuram, et iure divino, et iure canonico, et iure naturali prohibitam est".

Es más, en este momento aún se siguen contemplando poderes represivos de la usura otorgados a las autoridades eclesiásticas. En tal sentido, el Breve de CLEMENTE XIII sobre las facultades del Nuncio Apostólico en España, de 18 de diciembre de 1766 (recogido en la Novísima Recopilación, ley 4. ${ }^{a}$, Tít. IV, Libro II) establece como

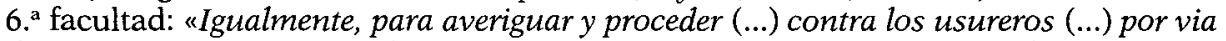
de acusacion, denuncia, ó de oficio, aunque sumaria, simplemente y de plano, y sin estrépito y figura de juicio».

${ }^{33}$ No obstante, todavía Hugo Grocio hizo intentos para justificar la licitud de los intereses incluso en los casos de préstamo. En tal sentido, vid. Ascarelli: Comentario a los arts. 1.282 a 1.284, en Obbligazioni pecuniarie, op. cit., pág. 579, nota 1.

En cualquier caso, la situación económica del momento hizo que los Comentaristas, si bien reafirmaban la posición de la doctrina canonista sobre el préstamo con intereses - como no podía ser de otro modo-, intentaran conciliar la prohibición con algunas situaciones en que la capacidad productiva del dinero admitía un cierto interés. De este modo, se intentó limitar el concepto de usura al contrato de préstamo, para seguidamente mantener que no todo lo exigido con ocasión del mismo podía considerarse usura, sino únicamente el lucro que excediera el legítimo interés.

${ }^{34}$ Así, las Capitulares de los carolingios (Cap. long., 813; L. long. Lothar., 15, 19) y los Estatutos municipales de muchas ciudades italianas, como Bolonia y Turín 
De la prohibición canónica quedaban exceptuados los judíos ${ }^{35}$-a los que por otra parte, obviamente, no les afectaba la sanción de excomunión-, que en gran número se dedicaron al préstamo sobre prendas, asumiendo prácticamente un monopolio ${ }^{36}$, y recayendo sobre ellos por este motivo un generalizado odio popular, de modo que judío llegó a ser sinónimo de usurero. En Francia, el artículo 10 de la Ordenanza real de 13 de marzo de 1630 permitió a los banqueros judíos percibir cuatro denarios a la semana por una libra o veinte sueldos ${ }^{37}$.

No obstante, los primeros pasos normativos en torno a la afirmación de la licitud de los intereses se dieron ya en el siglo XvI y en el ámbito germánico, quizás por su relativa desvinculación de la vigencia de la prohibición canónica de los intereses - ligada a la Iglesia católica- y en cambio aplicación de las teorías calvinistas sobre la licitud del beneficio económico ${ }^{38}$, con el Reichabschied de 1654, cuyo § 174 redimensiona la prohibición con la fijación de un límite, de aproximadamente el $6 \%{ }^{39}$, por debajo del que los intereses se considera-

(aunque no faltaban los Estatutos que sí permitían los intereses, como los de Verona o Parma).

35 Así, cfr. Constit. Sicil., I, 6; Constit. piem., I, 8, 5; Stat. Justinopolit., II, 76. En España se añadió, aunque en menor medida, a los musulmanes. De este modo, junto a una usura tolerada, hay una usura admitida.

${ }^{36}$ No obstante, desde el siglo xIII ya se observan repetidos intentos por restringir los privilegios de los judios en tal sentido, que van desde una simple previsión de requisitos especiales (intervención obligatoria de escribano cristiano; registro público de judíos prestamistas, que debían jurar solemnemente con carácter anual el acatamiento de la tasa...) en la Corona de Aragón (Fueros de Aragón de 1247, IV, fuero 1 de usuris; Constitutions de Cathalunya, III, 4, 6; Confirmatio fororum et libertarum regni Valenciae de 1283) y en Navarra (Amejoramiento del Fuero de 1330, de Felipe III el Atrevido, Cap. $\mathrm{XV}$ ) hasta, en Castilla, la prohibición de la usura judia (Cortes de 1405) e incluso la presunción de que todas las obligaciones entre judíos y cristianos eran usurarias, admitiéndose sólo aquellas con prestaciones simultáneas (Cortes de 1462). Sobre ello, vid. Clavero: Usura. Del uso económico..., op. cit., págs. $42-43$ y 52-53.

37 Cfr. Planiol, Marcel y RIPERT, Georges: Derecho civil, trad. por Leonel PerezNIETo CASTRo, Ed. Pedagógica Iberoamericana, México, 1996, pág. 105.

38 Mientras que, en cambio, LuTERo se mostraba contrario a la licitud de los intereses. Sobre el influjo del protestantismo en el desarrollo del capitalismo moderno, vid. Álvarez CAPEROCHIPI, José Antonio: "Capitalismo y protestantismo", Centenario del Código Civil (1889-1989), T. I, Asociación de Profesores de Derecho Civil, Ed. Centro de Estudios Ramón Areces, Madrid, 1990, págs. 51-71.

39 En la práctica, no se admitían intereses superiores al 5\%, tanto retributivos como moratorios (vid. Roll, Achim: "Die Höhe der Verzugszinsen", DRiZ, T. 51, 1973, pág. 341, en especial nota 17). En el mismo sentido se pronunciará en Prusia el $A L R$ de 1794, que establece respecto de ambos tipos de intereses un límite del $5 \%$ para particulares (Theil I, Titel XI, $\$ \S 804,830$ y 841 ), del $6 \%$ para comerciantes (Theil I, Titel XI, §§ 805 y 832 ) y del $8 \%$ para judíos (Theil I, Titel XI, § 805). 
ban lícitos y por encima del cual la disposición de dinero podía en cambio considerarse de naturaleza usuraria.

\section{II.3. LA SUPERACIÓN DE LA PROHIBICIÓN CANÓNICA DE LOS INTERESES}

Sin embargo, pese a la existencia de la prohibición canónica, se ha dicho que si en la economía occidental ha habido un principio, una regla siempre y en todas las situaciones contradicha por una práctica contraria $^{40}$, ésta fue la relativa al préstamo con intereses; y si hay un principio antiguo como la regla prohibitiva recogida en el Deuteronomio, confirmado como principio de valor universal e integrado en la legislación civil pero siempre rebatido, éste fue la prohibición de tal préstamo ${ }^{41}$. El problema en el fondo se limitaba a la búsqueda de

${ }^{40}$ En tal sentido, se recurría particularmente al contrato de mohatra y al trinus contractus (también denominado "contrato germánico»), a los que más adelante nos referiremos (vid. infra el aptdo. III.2).

Otro sistema, subsistente hasta tiempos relativamente recientes y empleado más como garantía que como modo de encubrir el propio préstamo, es el de los juicios convenidos, que se acogía a las peculiaridades de la justicia municipal (hasta el punto de que a fines del siglo XIX algunos juzgados municipales se habían convertido de hecho en verdaderas agencias de préstamos): antes de constituirse el préstamo, el prestamista acude al juzgado, y allí el prestatario reconoce la deuda a favor de aquél, allanándose a la demanda, con lo que el prestamista, al entregar el importe del préstamo, dispone ya de una ejecutoria. Se llegó incluso a tener impresos los correspondientes papeles, con los respectivos huecos. Para eludir la dificultad de que el importe del préstamo impidiera la tramitación de la demanda como de juicio verbal (y la excluyera de la justicia municipal), se fraccionaba el importe en tantas deudas (y tantas demandas) como fuera necesario (cfr. CoviáN: "Usura», EJE, T. XXX, Ed. Francisco Seix, Barcelona, s.f. —ca. 1922-, pág. 643; ESTASÉN, Pedro: "La ley sobre préstamos usurarios", RGLJ, T. CXIV, 1909, págs. 270-276, y T. CXVII, 1910, págs. 5-8; PERAY March, José de: "¿Son lícitos los juicios convenidos?", RJC, T. XIV, 1908, págs. 532-534; y Vizcarro, C. Fernando: El préstamo usurario, Col. Nereo, Barcelona, 1963, págs. 22-23).

41 Vid. Clavero: Usura. Del uso económico..., op. cit., pág. 40; Mazzoni, Cosimo Marco: Frutti civili e interessi di capitale, Ed. Giuffrè, Milán, 1985, pág. 19; y PlanIol y RIPERT: Derecho civil, op. cit., págs. 105-106. Asimismo, PERnOud, Regine: Histoire de la bourgeoisie en France. Des origines aux temps modernes, T. II, Ed. du Seuil, París, 1960, pág. 330; PIETTRE, Adam: Le trois âge de l'économie, Ed. Ouvrières, París, 1955, pág. 242; TARVERnEaUX, R.: Jansenisme et prêt à intérêt, Ed. Vrin, París, 1977, pág. 118. Debe igualmente tenerse en cuenta la existencia de excepciones a la prohibición para determinadas categorías de personas, como la ya referida de los judíos, los toscanos (vid. Stat. Paduae, c. 862), los "lombardos» - restos de ello quedan aún en el mercado financiero alemán, donde se habla de Lombardgeschäft, Lombarddarlehen, lombardieren, etc.- y finalmente los comerciantes en general [en tal sentido, INZITARI, Bruno: «Interessi», Digesto delle discipline privatistiche. Sezione civile, Vol. IX, Ed. 
un medio de ganar dinero sin pecar ${ }^{42}$, y en tal sentido los intereses fueron un fenómeno estrechamente ligado a la formación del capital comercial y al comienzo del desarrollo que experimentó el comercio en la Baja Edad Media, de modo que finalmente cuando la doctrina canónica terminó por admitir las usurae por exigencias de la econo-

UTET, Turín, 1993, pág. 570, nota 12 -y en Profili del diritto delle obbligazioni, Ed. CEDAM, Padua, 2000, pág. 229, nota 12-; "Gli interessi”, en La moneta (Vol. VI del Trattato di diritto commerciale e diritto pubblico dell'economia, dir. por Francesco GALGANo), Ed. CEDAM, Padua, s. f. (1983), pág. 195, nota 17, e «Interessi legali e maggior danno", Profili del diritto delle obbligazioni, Ed. CEDAM, Padua, 2000, pág. 107, nota 8].

Especialmente interesante es la exposición de Henri PIRENNE (Historia económica y social de la Edad Media, 13. ${ }^{\text {a }}$ reimp. de la 1. ${ }^{a}$ ed. en español, Ed. Fondo de Cultura Económica, Madrid, 1975, págs. 102-103, y notas 64 y 67 en págs. 176-177; las negritas son nuestras): en los primeros siglos de la Edad Media, los propios establecimientos eclesiásticos habían desempeñado el papel de verdaderos establecimientos de crédito, pero a partir del siglo XIII (recordemos, época de la construcción tomista en torno a los intereses) rara vez intervinieron como prestamistas, pues además de que difícilmente podían competir con los mercaderes (sobre todo los financieros italianos), con quienes incluso frecuentemente estaban endeudados, "no podían, como los laicos, eludir la prohibición del préstamo con intereses [ergo los laicos la eludían], aunque a veces se hayan permitido violarla", y así en 1228 el abad de Saint-Bertin prestaba dinero ad usuram. Por otra parte, se generalizó el empleo de figuras alternativas al mutuo con intereses como modo de eludir la prohibición: rentas o «supercensos» sobre casas, que con un interés «mucho más módico que el interés comercial, ofrece la ventaja de no estar sujeto a la prohibición de la usura y fluctúa generalmente entre el 10 y el 8\%, a fines del siglo $X \mathrm{~V}$ »; rentas vitalicias, pagaderas durante "una o dos vidas» (hasta la muerte del prestamista o la de sus herederos) y utilizadas frecuentemente por las villas a partir del siglo XIII como medio de procurarse recursos extraordinarios (aunque también las abadías constituían rentas vitalicias a favor de sus acreedores)...

42 En tal sentido, se recurrió a contratos alternativos al mutuo con intereses, que quedaran fuera de la prohibición canónica, como la constitución de renta, las ventas con pacto de retro (de modo que el prestamista compraba la cosa del prestatario reservándose éste el derecho de recomprarla por un precio mayor, y la diferencia entre ese precio y el originario constituirían los intereses encubiertos), la venta con arrendamiento (estipulada una venta con pacto de retro, el comprador «arrienda» la cosa al vendedor por un precio que constituye en realidad unos intereses), el contrato pignoraticio, la mort-gage (especie de prenda que recaía sobre cosa fructífera en la que el acreedor percibía como intereses los frutos de la cosa que se le daba en pignoración), el interusurium, los censos, las rentas... ESCRICHE [»Interés c)», op. cit., págs. 166-167] señala como contratos admitidos, equivalentes al mutuo con intereses, el contrato trino, el censo consignativo y la compraventa con pacto de redención o retroventa.

Se llegaron a realizar construcciones tan alambicadas como entender que el préstamo a intereses podía entenderse como una participación del prestamista en las pérdidas y ganancias del prestatario, determinada a forfait en la cuantía del capital más los intereses. Igualmente, en la mitad del siglo XVII se habían llegado a proponer soluciones tan peregrinas como la que «sólo consiste en el uso de ciertas palabras que hay que pronunciar al prestar el dinero; después de las cuales se puede obtener beneficio 
mía, a fin de distinguirlas de las devengadas ilícitamente las llamó «intereses» (interesse, id quod interest), como indemnización justa por la privación temporal de la cantidad prestada ${ }^{43}$, en una línea de pensamiento que en fechas tan relativamente recientes como 1880 aún seguía afirmando que «el préstamo es gratuito por su naturaleza (...). Permítese, no obstante, estipular algun interés en el préstamo de cosas que se consumen por el uso, para indemnizar al prestamista de los perjuicios que pueda experimentar por la privacion de las cosas que presta, para compensarle del daño emergente ó del lucro cesante ó naciente ${ }^{44}$.

sin temor a que sea usurario, como lo habría sido sin duda de otro modo"; "aquel a quien se pide dinero contestará de esta manera: "no tengo dinero que prestar; sí lo tengo para poner a rédito honrado y lícito. Si deseáis la suma que pedís para hacerla fructificar por vuestra industria yendo a medias en ganancias y pérdidas, tal vez me decidiese. Bien es verdad que a causa de lo difícil que es ponerse de acuerdo sobre el beneficio, si me queréis garantizar uno seguro y también el capital de la renta, de suerte que no corra ningún riesgo, nos pondríamos pronto de acuerdo y os entregaría el dinero ahora mismo" (BAUNY, Etienne: Suma de los pecados, prefacio, cit. por PASCAL, Blaise: "Octava carta escrita a un provinciano por uno de sus amigos», en Obras. Pensamientos. Provinciales. Escritos científicos. Opúsculos y cartas, 2. ${ }^{\text {a }}$ ed., pról. de José Luis ARAnguren, trad. y notas de Carlos R. de DampierRe, Ediciones Alfaguara, Madrid, 1983, pág. 126; las comillas interiores de la última frase son del original). Ello hace que en esta época PASCAL ironice sobre estos razonamientos: «he aquí unas palabras muy fuertes; os juro que si no supiese que proceden de buena fuente, las tomaría por algunas de esas palabras mágicas que tienen el poder de romper un encantamiento. Sin duda tienen alguna virtud oculta para alejar la usura que yo no comprendo; porque siempre he pensado que ese pecado consistía en obtener más dinero que el que se ha prestado" (ibid.).

En el fondo suponía seguir, aunque tal vez de un modo extremo, la doctrina del moralista jesuita Antonio EsCOBAR y MENDOZA, quien sostenía que la moralidad de las acciones dependía de la intención moral del individuo y no del valor objetivo de las acciones mismas (y que fue rechazada por muchos, entre ellos el propio PASCAL, como una excusa para el relajamiento moral). En tal sentido se entiende que la usura «no consiste más que en la intención de obtener un beneficio como usurero. Y por eso es por lo que nuestro padre Escobar consigue evitar la usura con una simple desviación de intención. Está en el tr. III, ex. 5, n. 4, 33, 44: Sería usura, dice, obtener beneficio de aquellos a quienes se presta, si se exigiese como debido en justicia; pero si se exige como debido por agradecimiento, no es usura. $Y$ en el n. 3: No está permitido tener intención de aprovecharse del dinero prestado directamente, pero pretenderlo por medio de la benevolencia de aquel a quien se ha prestado (...) no es usura" (PASCAL: "Octava carta...", op. cit., pág. 126; las redondas se corresponden con cursivas del original).

${ }^{43}$ Cfr. Clavero: «Interesse: traducción e incidencia de un concepto en la Castilla del siglo XVI", AHDE, T. XLIX, 1979, 39-97 (también en: Usura. Del uso económico..., op. cit., pág. 60-100).

44 Así, Allende Salazar, A.: «Definición del interés: sus clases», en «Cuestiones de Derecho civil», $R G L J$, T. LVI, 1880, págs. 629-630; las redondas se corresponden con cursivas del original. 
En tal sentido, sobre todo a partir de la citada Encíclica Vix Pervenit de 1745 -que, como vimos, relajaba en cierto modo la prohibición canónica-, se aceptaba (aunque no por todos los autores) que sí sería admisible el devengo de intereses de incurrirse en alguna de estas circunstancias o títulos justificativos (los antes citados «requisitos del Castrense»): periculum sortis, damnum emergens y lucrum cessans. Con la primera se admitió la generación de intereses en situaciones de especial riesgo para el capital, principalmente en el tráfico comercial marítimo ${ }^{45}$, si bien se distinguían un peligro intrínseco o general, que es de temer en todo mutuo y por el que nada podría reclamarse, y un peligro extrínseco o especial, proveniente de la calidad del mutuatario o de la negociación, por el que sí se podría reclamar una compensación proporcionada ${ }^{46}$. Con las otras dos, se justificaron los intereses moratorios en las obligaciones de dinero. De este modo, dado que difícilmente habría un préstamo en que el que no concurriera alguna de estas tres circunstancias, la interdicción radical de los intereses quedó privada de virtualidad efectiva.

Sin embargo, todavía en las Decretales subsistía nominalmente la prohibición, y es en 1821 cuando la Sagrada Congregación del Santo Oficio reconoce que por sí mismo el préstamo con intereses no era pecado. No obstante, no será hasta ya el siglo xx cuando la legislación canónica admita (si bien de un modo sólo indirecto) la licitud del devengo de los intereses. Así, en el Código de Derecho Canónico (CIC) de BENEDICTO XV, de 27 de mayo de 1917, al tratar del contrato de préstamo $^{47}$, se recoge y flexibiliza la doctrina que se contenía en la Encíclica Vix Pervenit: en el contrato de préstamo, al ser de suyo improductiva la cosa fungible, no es lícito exigir ningún tipo de lucro,

${ }^{45} \mathrm{Al}$ igual que ya sucedió con el foenus nauticum o pecunia traiecticia, de época romana.

${ }^{46}$ El título justificativo del periculum sortis era ya reconocido con anterioridad a la Vix pervenit. Así, a consultas de misioneros en China, respondieron el 12 de septiembre de 1645 los calificadores del Santo Oficio y de la Sagrada Congregación para la Propagación de la $\mathrm{Fe}$, con aprobación pontificia: "por razón del mutuo inmediata y precisamente ningunos intereses podian pedir los mutuantes o prestamistas; pero que si exigían algo por el peligro que probablemente había según lo consultado, no se les debía inquietar de modo alguno, con tal que se tuviese cuenta de la calidad y probabilidad del peligro, y se guardase proporción entre el mismo peligro y los intereses exigidos".

${ }_{47}$ Canon 1.543: «I.- Si se da a uno alguna cosa fungible de modo que la propiedad pase al mismo y después haya de devolver otro tanto en la misma especie y calidad, no puede percibirse lucro alguno por razón precisamente del mismo contrato de préstamo. III.- Sin embargo, al prestar una cosa fungible, no es de suyo ilicito pactar que se paguen los intereses legales, a no ser que conste que son excesivos, o también otro lucro superior, con tal que exista título justo y proporcionado para ello". 
pero en cambio, si existiera un título legítimo extrínseco (sea el lucro cesante, el daño emergente o el peligro de perder el capital prestado), podrá percibirse el lucro que corresponda a dicho título ${ }^{48}$.

\section{TRATAMIENTO DE LOS INTERESES EN EL DERECHO ISLÁMICO}

\section{III.1. LA PROHIBICIÓN DE LA RIBÄ}

El Derecho islámico (shari'a), con base en el Corán ${ }^{49}$, recoge en general una prohibición de los intereses (ribā) similar a la que -como hemos visto- se produjo en Europa en el Derecho canónico medieval. Sin embargo, a diferencia de éste, la prohibición realizada por la shari'a continúa hasta hoy, al menos nominalmente.

48 El actual Código de Derecho Canónico (CIC), de 25 de enero de 1983, en su canon 1.290 se remite, respecto de los contratos, al Derecho civil de cada territorio, por lo que cabe entender que acepta plenamente, al menos en el caso de España (y de la mayor parte del mundo), la licitud del préstamo con intereses.

49 Sura 2, a. 275-276 y 278-279: "Quienes negocian a través de la usura están continuamente en un estado de descontrol y desorden, en todas sus acciones y empresas y en cualquier estado y situación en que se hallen. Su caso es el de alguien al que Satanás hubiera corrompido su razón y comenzó a tropezar y errar, debido a su locura. Pretenden asimilar la venta con la usura, con el argumento de que en ambos procederes existen ofertas y beneficios y que por tanto ambos son licitos. Dios ha refutado su pretensión y les ha demostrado que la licitud y la ilicitud son de Su manejo, y que el argumento similar que sostienen no es veraz ni real. Dios decretó lícita la actividad de vender y decretó ilicita la usura. A quien llegue la disposición de su Señor prohibiendo la usura debe guiarse por ella. Se quedará con lo obtenido con la usura, antes de su prohibición, y su caso penderá del perdón de Dios. Mas quien vuelva a negociar por medio de la usura haciéndola permisible luego de saber su prohibición, entrará al fuego infernal y permanecerá en él por siempre. / Dios hace desaparecer lo obtenido de más por medio de la usura, y bendice la riqueza y los bienes de los cuales se toma para caridad. Recompensa a los dueños, acrecentándoles redobladamente las riquezas y los bienes. Dios no ama a quienes se empecinan en dar por lícitas las prohibiciones como la usura. / (...) / Creyentes, tened temor y prevención de Dios; mantened Su majestad en vuestro corazones y renunciad a exigir lo que aún no recibisteis de lo producido por la usura, si es que en verdad sois creyentes. /Y si no cumplís con lo que Dios os ha ordenado de abandonar la usura, estad seguros de que entráis en guerra con Dios y con el Profeta por oponeros obstinadamente a Su mandato. Si queréis que se acepte vuestro arrepentimiento, entonces reclamad sólo vuestros capitales y no toméis de ellos nada más, sea poco o mucho, y cualquiera que haya sido el motivo de la deuda y la forma en que se utilizó. Cobrar más sobre el capital es injusticia y opresión para el deudor. Restituiros vuestros capitales con mengua o disminución es injusticia y opresión para vosotros" [según Consejo Superior de Asuntos Islámicos de Egipto (ed.): Al-Montajab. "La Selección» en la Interpretación del Sagrado Qur'an, (Universidad de) Al Azhar, El Cairo, 2001, págs. 90-91; las negritas son nuestras]. 
Así, en la actualidad no se pacta el devengo de los intereses por parte de los bancos islámicos, y en ciertos países (como Arabia Saudí, Libia, Irán y Pakistán) la prohibición de la ribā es estrictamente respetada. En cambio, en Túnez sí se admite la plena licitud de los intereses, y por otra parte, en los países en que la legislación no se pronuncia, ha sido la jurisprudencia la que ha oscilado entre considerar que es plenamente vigente la prohibición coránica (Emiratos Árabes Unidos, Kuwait o Marruecos) o que son admisibles los intereses aunque sometidos a un límite cuantitativo (Egipto, Siria o Irak).

\section{III.2. LAS HIYAL. EN ESPECIAL, EL MOHATRA}

La conciliación de la obligación de respeto al Derecho religioso con la necesidad de la configuración de una situación atractiva para las inversiones y la colocación de capitales ha impulsado que se recurra a subterfugios (hiyal) ${ }^{50}$, cuya licitud es reconocida por el propio Derecho islámico, hasta el punto de que en las escuelas jurídicas se llegó a crear una verdadera ciencia de las hiyal ('ilm al-hiyal). Estas hiyal son, principalmente, las siguientes:

- La venta o arrendamiento con condición resolutoria (Khiar ach chart), combinada con el pago anticipado del precio.

- La venta con pacto de retro (bay' al-wafä', bay' al-'uhda), similar al concepto que de la misma tenemos en el Derecho español.

- El bay wa salaf, contrato consistente en dos operaciones distintas: un préstamo gratuito, que es el contrato principal, y un contrato de venta, del prestamista al prestatario, de un objeto de valor mínimo, pagándose como precio de este objeto la cuantía de los intereses.

- Y, por último, incluso el contrato de comisión, estructurándolo de la siguiente forma: A encarga a $B$ la adquisición de una mercancía por 10 , y finalmente se la abona por 12 después de tres meses.

Pero, de todos los subterfugios o hiyal empleados para eludir la prohibición de la ribā, destaca especialmente la utilización de la venta doble (Baya'tani fi bay'ah), que se produce cuando A vende a B un

${ }^{50} \mathrm{Al}$ respecto, vid. CARDAHI, Choucri: "Le prêt a intérêt et l'usure au regard des législations antiques, de la morale catholique, du droit moderne et de la loi islamique (Analyse et synthèses comparatives)", Rev. Int. D. Comp., T. VII, N. ${ }^{\circ}$, julio-septiembre 1955, págs. 532-534. 
objeto por 400 dinares pagables a tres meses, y se lo recompra simultáneamente por 300 dinares pagables al contado o a un corto plazo; B recibe inmediatamente (o en un plazo breve) el precio de 300 dinares, que es en realidad la suma prestada, y al fin del trimestre pagará 400 dinares, el precio del objeto vendido, que en realidad representa la devolución del préstamo aumentado por los intereses.

Esta venta doble terminó derivando en la figura denominada inah o muhātarah, y finalmente se consideró que había inah en todo caso en que entre lo que el vendedor cedía y lo que recibía hubiera una diferencia, sea de cantidad, sea de calidad, como cuando se vendía una cosa de 80 dinares por 100, a pagar en tres meses. Lo extendido de la inah o muhātarah hizo que esta última denominación se acogiera en la Europa medieval para designar el contrato de mohatra o contractus mohatrae, empleado como subterfugio para eludir la prohibición canónica de los intereses y de gran difusión en la época ${ }^{51}$. Esa especial importancia del contrato de mohatra - aplicación europea de la inah musulmana- exige que, siquiera brevemente, apuntemos unas notas sobre el mismo.

En concreto, este contrato de mohatra es definido por PASCAL ${ }^{52}$ como aquél por el que «se recibe cierta suma al contado quedando comprometido por una suma mayor», describiéndolo con estas palabras: "el contrato Mohatra es aquel por el que se compran telas a precio elevado y a crédito para revenderlas al momento a la misma persona, al contado y baratas" ${ }^{53}$; así "cuando un hombre que tiene necesidad de veinte pistolas ${ }^{54}$, compra a un mercader de tejidos por valor de treinta pistolas pagaderas en un año y se lo revende al mismo por veinte pistolas al contado" ${ }^{55}$. Es decir, consiste en dos ventas simuladas: una al contado, hecha por el prestatario al prestamista, y una recompra a crédito de la misma cosa por un precio superior, que el prestatario deberá pagar en el momento del vencimiento y cuya diferencia con el precio de la primera venta constituye los intereses, y cuyo origen puede encontrarse en el Derecho romano postclásico bizantino ${ }^{56}$.

51 Como mencionamos incidentalmente con anterioridad.

${ }^{52}$ Cfr. Pascal: «Octava carta...», op. cit., pág. 127 (todas las cursivas en las citas que siguen son del original).

53 Citando a EscobAr: tr. III, ex. 3, n. 36.

54 La pistola era una moneda de oro española e italiana que en 1690 tenía un valor de once libras y el peso de un luis. En Francia se empleaba la denominación en lenguaje corriente para designar las monedas de diez francos.

55 Citando la obra Epilogus Summarum, pág. 54. 80-88.

56 Vid. D., 12, 1, 11 pr. y B., 23, 1, 11; cfr. Gómez RoYo: El mutuo..., op. cit., págs. 
Si bien el mohatra se consideraba en principio prohibido ${ }^{57}$, se podía hacer lícito «a pesar (...) de que aquel que vende y recompra tenga como intención principal el propósito de obtener un beneficio, con tal, solamente, de que al vender no exceda del precio más alto de los tejidos de esa clase, y que al volver a comprar, no pase del más bajo; y que no se convenga antes sobre ello en términos expresos, ni en ninguna otra forma " ${ }^{58}$, y más allá aún, Lessius ${ }^{59}$ entiende que «incluso si se hubiese convenido, jamás se está obligado a devolver el beneficio, si no es tal vez por caridad, en el caso de que aquel de quien se exige se hallase en la indigencia; e incluso con tal de que se pueda devolver sin perjudicarse ${ }^{60}$.

${ }^{57}$ Así, por ej., en España vid. lo establecido al respecto por la ley 5, Tít. XXII, Libro XII de la Novísima Recopilación, que recoge la Nueva instrucción para los Alcaldes mayores de los Adelantamientos, de 3 de marzo de 1543, de Carlos I y JuAna I.

58 Aquí Pascal (loc. cit.) vuelve a citar a Escobar.

59 Cfr. De Just., l. II, c. 21, d. 16.

${ }^{60}$ Sobre el contrato de mohatra, vid. el extenso estudio de Ernesto Simonetro (Los contratos de crédito, trad. por Juan MARTínez VALENCIA y anotado por Juan V. FuENTES LoJo, Ed. J. M. ${ }^{a}$ Bosch, Barcelona, 1958, págs. 329-336) y la bibliografía que cita, y FuENTES Lojo (Anotaciones a Los contratos de crédito, op. cit., págs. 337-338). Sobre una variante moderna del contractus mohatrae (según la cual se acuerda que una parte entregará a la otra un objeto con facultad de enajenarlo en nombre propio para convertirlo en dinero, y retener el producto como un mutuo), vid. ENNECCERus, Ludwig: Derecho de obligaciones (T. II del Tratado de Derecho civil de Ludwig ENNECCERUS, Theodor KIPP y Martin WolfF), Vol. 2. ${ }^{\circ}-1 .^{\circ}, 11 .^{a}$ ed. revis. por Heinrich LeHManN, 2. ${ }^{a}$ ed. española, al cuidado de José Puig BruTau, Ed. Bosch, Barcelona, 1954, pág. 414; Blas Pérez González y José Alguer (en sus Anotaciones al Derecho de obligaciones de ENNECCERUS, Vol. $22^{\circ}-1 .^{\circ}$ op. cit., pág. 419) consideran aplicable esta construcción también al Derecho español (curiosamente, en un caso tan reciente como el resuelto por la STS de 17 de marzo de 1998 se invoca por una de las partes que el contrato en discusión, de los denominados de lease-back, en realidad no encubría más que un contrato de mohatra, calificación en la que el Tribunal no entra).

En la Edad Media tiene su origen también una figura similar al mohatra y que igualmente busca eludir la prohibición de las usurae, vigente a la sazón: el trinus contractus (también denominado «contrato germánico»), según el cual se entrega a un comerciante un capital en participación, asegurado mediante un premio de la restitución de todo el capital incluso en caso de haber pérdidas, e igualmente se vende a ese mismo comerciante la parte de incierto beneficio parciario por un precio (normalmente, el $5 \%$ de la suma entregada). Así, consiste en realidad en una operación societaria en la que se combinan tres contratos en uno solo (de ahí su nombre): uno de cuentas en participación, uno de seguro y uno de compraventa. El origen de este contrato ha sido atribuido a los canónigos orientales, al navarro del siglo Xvi Martín AzPILCUETa (quien lo habría inventado a solicitud del rey de Portugal para que los comerciantes de Lisboa pudieran contraer préstamos sin incurrir en usura) y a los griegos. 


\section{I.3. LA TIPOLOGÍA DE LA RIBĀ A EFECTOS DE SU PROHIBICIÓN}

Tradicionalmente se ha considerado que en realidad habría dos tipos de rib $\bar{a}^{61}$ : una en la que el beneficio del acreedor sería el resultado de una obligación pecuniaria (ribà al-nasā'a, que determina el campo de la usura en sentido técnico), y otra en la que ese beneficio resulta de un desequilibrio entre las prestaciones relativas al intercambio de bienes o a la prestación de servicios ( $r i b \bar{a}$ al-fadl), ligada a la distinción $^{62}$ entre obligaciones dayn (de naturaleza pecuniaria, y por ello objeto de mayor atención por su mayor facilidad de recaer en la ribā) y obligaciones 'ayn (de intercambio de cosas, y por tanto preferidas dada la presencia de una cosa que garantiza la licitud de la relación obligatoria y justifica la ganancia derivada de ella).

De este modo, se ven más favorablemente los contratos de intercambio en que las prestaciones se cumplen simultáneamente, sobre todo cuando tienen por objeto bienes que pueden cambiar de calidad y valor en el tiempo, a fin de evitar que una de las partes pueda, con especulaciones ilícitas, obtener un beneficio que no sea proporcionado, equitativo y justificado por la actividad de las partes o la finalidad del contrato. En esta línea, se considerarán ribā los excesos de cantidad o diferencias de calidad respecto de lo pactado, los servicios prestados por el deudor más allá de la prestación principal y fuera del acuerdo inicial de las partes, y los retrasos o modificaciones del cumplimiento (incluido su lugar), y en tales casos serán nulas (fāsid) las obligaciones en que no haya proporción entre los beneficios y sacrificios de las partes y el bien o servicio objeto del contrato, de modo que todo enriquecimiento injustificado será ribā.

${ }^{61}$ Cfr. Piccinelli, Gian Maria: «Ribā», Digesto delle Discipline Privatistiche. Sezione civile, T. XVII, Ed. UTET, Turín, 1998, págs. 495-496.

${ }^{62}$ Con base en el Corán, sura 2, a. 282: “Creyentes, si os hacéis préstamos entre vosotros por plazos a futuro, es preciso que el plazo sea fijado y conocido. Ponedlo por escrito para asegurar derechos y evitar discusiones (...) no descuidéis formalizar la escritura, sean montos pequeños o grandes, si es que está condicionada a pagos futuros. Esto es más justo para la Ley de Dios y más firme en señalar la legitimidad del testimonio y más efectivo en evitar que surjan dudas entre vosotros. No será necesario escribirlo si se trata de una negociación comercial del momento que realicéis entre vosotros (...)». Cita que realizamos según la versión del Consejo Superior de Asuntos Islámicos de Egipto (ed.): Al-Montajab..., op. cit., pág. 92. 


\section{III.4. ORIENTACIONES FAVORABLES A LOS INTERESES}

No obstante lo que hemos indicado con anterioridad, últimamente han surgido en el ámbito islámico algunos autores ${ }^{63}$ que abogan por una interpretación distinta de la riba $\bar{a}$, similar a la que como vimos se realizó en Europa a partir del siglo XVIII, en relación con la doctrina canónica sobre los intereses, con base en que la prohibición coránica se basaría en consideraciones morales y humanitarias, no jurídicas, y que lo prohibido es básicamente la explotación de las necesidades de una persona en dificultades financieras, más que un «incremento» acumulado al acreedor en un préstamo.

Para estos autores, un "incremento» que se da al acreedor en una transacción financiera no debería considerarse ribā sólo el mero hecho de ser un incremento: no todos los supuestos de intereses son rib $\bar{a}$, sino que sólo lo serían aquéllos que supongan una falta de equidad para alguna de las partes. De esta forma, serían las circunstancias de cada operación particular, sus partes, el poder relativo de cada parte frente a la otra y el entorno económico y social lo que debe determinar si una operación en concreto debería ser prohibida como ribā.

A lo largo de la Edad Media, la literatura fiqh fue configurando cada vez más esas consideraciones morales y humanitarias como propiamente jurídicas, y se restringió la institución del préstamo (qard) a propósitos humanitarios, por lo que hubo de acudirse a los ya referidos hiyal o subterfugios para los préstamos con fines distintos de las necesidades básicas de las personas. En la actualidad, los intentos por autores más vanguardistas, como Fazlur RAHMAN, de aproximarse a la riba y a su prohibición en términos más flexibles y enfatizando que la base de la prohibición coránica sería la falta de equidad, han chocado con ciertas escuelas jurídico-religiosas islámicas conservadoras, que han establecido la interpretación tradicional como norma inmutable del Derecho islámico, bloqueando cualquier intento de entender la materia de la ribä desde una perspectiva estrictamente moral.

Sin embargo, la interpretación tradicional ha entrado en colisión con el enorme desarrollo que desde la década de los 70 han experimentado varios países petroleros árabes, que les ha llevado a fundar bancos islámicos y centros islámicos de estudios bancarios y financieros.

63 Vid., por todos, SAEED, Abdullah: Islamic banking and interest. A study of the prohibition of Riba and its contemporary interpretation, Ed. E. J. Brill, Leiden/Nueva York/Colonia, 1996. 
Inicialmente, los bancos islámicos intentaron aplicar la interpretación tradicional de la riba utilizando como base, sobre todo en sus operaciones inversoras, conceptos del Derecho islámico como la mudāraba y la musharaka (reparto de pérdidas y ganancias), pero la experiencia no fue satisfactoria, y pronto encontraron que no podían usar los conceptos tal y como fueron desarrollados en la shari'a, al tender demasiado al riesgo. Los bancos islámicos se encontraron con que debían ser islámicos a los ojos de sus clientes, a la vez que rentables en la inversión en negocios de bajo riesgo o sin riesgo para el beneficio de estos clientes y de sus accionistas. Por ello, tuvieron que despojar las dos figuras de la mudāraba y la musharaka de varias de sus características básicas a fin de convertirlas casi en negocios a corto plazo sin riesgo, en que el banco podía adelantar un capital sobre la base de una devolución más o menos predeterminada.

Sin embargo, lo estrecho del margen que esto les permitía llevó a que los bancos islámicos recurrieran a otros mecanismos sin riesgo del Derecho islámico, desarrollados por sus asesores jurídicos y religiosos, como la murabaha (venta con devolución predeterminada), el bay'mu'ajjal (venta con pago aplazado) y la ijara (arrendamiento), adaptándolos a fin de hacerlos prácticamente equivalentes a un préstamo con intereses.

En cambio, en relación con los depósitos los bancos islámicos sí han seguido una aplicación estricta de la interpretación tradicional en torno a la ribā, y niegan la retribución con cualquier tipo de intereses a sus depositantes, incluso como compensación por su pérdida de valor por la inflación: han destacado que los bancos en el Derecho islámico, como mudarib, no pueden ser hechos responsables por sus fondos.

Precisamente por la necesidad de disponer también en los países islámicos de instrumentos económicos adecuados a las exigencias de la economía internacional moderna, ya desde inicios del siglo $\mathrm{XX}$ ha existido una importante corriente doctrinal tendente a la admisión de la licitud de los intereses bancarios, corriente que ha encontrado acomodo incluso dentro de las propias autoridades religiosas ${ }^{64}$.

Así, Mohamed 'ABDUH, mufti de Egipto de 1899 a 1905, declaró en una fatwā de 1903 (publicada en 1905) la licitud de los intereses pagados por los depósitos en las cajas de ahorro. Al efecto, distingue entre el interés usurario (el más radical, que se producía en la época preislámica) y la «participación en los beneficios de un negocio líci-

${ }^{64}$ Cfr. Piccinelli: «Ribā», op. cit., págs. 496-497. 
to», y considera lícito el interés bancario siempre que tenga la naturaleza de un "dividendo» o una "ganancia» derivados de los beneficios de la gestión general de la caja de ahorros (con lo que, sin nombrarlo, está haciendo referencia a un sistema de mudāraba).

También en esa línea, su discípulo el shayh Mahmād SHaLtūt introdujo desde 1957 argumentos éticos para defender la licitud de la percepción de intereses por los depósitos bancarios, subrayando los valores de solidaridad (takāful) y cooperación social (ta'āwwun), que se traducen en los efectos económicos positivos que se derivan del empleo productivo del dinero que reciben los bancos. Así, afirma que quien realiza un depósito sabe que el banco empleará su dinero en operaciones comerciales con un específico valor económico, del que se podrán beneficiar, además de los titulares de los fondos, los empleados del propio banco, el Estado y toda la sociedad. De esta forma, buscando salvaguardar e incrementar su propio capital a través del ahorro, el musulmán podrá conseguir lícitamente un «beneficio» como parte de una utilidad económica y social más amplia, y ese beneficio no será consecuencia ni de los intereses sobre una deuda que puedan considerarse ribā ni de los rendimientos de un préstamo que lleguen a estar legalmente prohibidos, sino que es un incentivo al ahorro y a la cooperación respaldada por la shari'a.

Finalmente cabe citar también entre los autores de esta corriente al mufti egipcio Mohamed SaYYid TanTaWT, que desde 1989 viene afirmando la licitud de los intereses pagados por el Estado por los títulos de deuda pública (shahadāt al-istihmār) y los bonos del Tesoro (udhān al-hizāna). Mediante los fondos recibidos con la venta de tales títulos, el Estado puede realizar operaciones de utilidad social que mantienen el desarrollo económico del país, y en este caso los intereses (que normalmente se denominan $f_{\bar{a}}^{\prime} i d a$ ) pasan a denominarse utilidad (' $a$ 'id), suponiendo tanto la cuota de beneficio derivada de las inversiones públicas que corresponde a cada ahorrador como el incentivo para la movilización de los capitales como instrumento de solidaridad y cooperación social.

Asimismo se ha pronunciado en este sentido un importante sector «laico» de la doctrina árabe, menos ligado a los esquemas religiosos tradicionales y por tanto sobre argumentos más racionales y menos ético-religiosos, en el que destaca 'Abd al-Razzāq Ahmad AL-SANHÜRI ${ }^{65}$,

65 Padre del Código Civil egipcio de 1949 y del iraquí de 1951, así como indirectamente de los que se derivan de ellos. Esta interpretación se observa también en $\mathrm{Al}$ Montajab...,op. cit., nota 1 a la sura 2, a. 275, pág. 90. 
que distingue entre la usura preislámica (riba al-gāhiliyya) y la usura (en el sentido de intereses) en los intercambios (riba al-fādl) y en los créditos (ribā al-nasā'a); la segunda es un medio para llegar a la tercera, que a su vez es el presupuesto de la primera, que será lícita sólo en caso de extrema necesidad (darāra) mientras que las otras serán admisibles por simple necesidad (haga). Con esta posición, será el legislador quien establezca la "gravedad" mínima de los intereses por debajo de la cual puedan considerarse aceptables, y así en los Códigos nacidos bajo el influjo de SANHURI se fija, junto al tipo de interés legal, un tipo máximo de intereses hasta el cual las partes pueden acordarlos libremente, y en otros países es la jurisprudencia la que - con referencias a las obras de SANHŨRI- establece un tipo de interés legal como límite de referencia para la reducción de los intereses convencionales.

\section{BIBLIOGRAFÍA}

Allende Salazar, A.: «Definición del interés: sus clases», en «Cuestiones de Derecho civil», RGLJ, T. LVI, 1880, págs. 629-630.

ALPA, Guido: «Usura: problema millenario, questioni attuali», NGCC, N. ${ }^{\circ} 12 / 1996$, parte $2{ }^{a}$, págs. 181-183.

Álvarez CAPERochIPI, José Antonio: «Capitalismo y protestantismo», Centenario del Código Civil (1889-1989), T. I, Asociación de Profesores de Derecho Civil, Ed. Centro de Estudios Ramón Areces, Madrid, 1990, págs. 51-71.

Ascarelli, Tullio: Comentario a los artículos 1.282 a 1.284, en Obbligazioni pecuniarie, Libro IV, artt. 1277-1284, del Commentario del Codice Civile, dir. por António SCIALOJA y Giuseppe BRANCA, Ed. Nicola Zanichelli-Soc. editora del Foro Italiano, Bolonia-Roma, 1959, págs. 575-593.

BUTERA, Antonio: «Usura», Digesto Italiano, Vol. XXIV (unioni internazionali-zucchero), Ed. UTET, Turín, 1914-1921, págs. 120-140.

CARDAHI, Choucri: «Le prêt a intérêt et l'usure au regard des législations antiques, de la morale catholique, du droit moderne et de la loi islamique (Analyse et synthèses comparatives)», Rev. Int. D. Comp., T. VII, N. ${ }^{\circ} 3$, julio-septiembre 1955, págs. 499-541.

Clavero, Bartolomé: "Interesse: traducción e incidencia de un concepto en la Castilla del siglo XVI», AHDE, T. XLIX, 1979, págs. 3997. 
Usura. Del uso económico de la religión en la historia. Ed. Tecnos. Madrid, 1984.

Consejo Superior de Asuntos Islámicos (ed.): Al-Montajab. «La Selección» en la Interpretación del Sagrado Qur'an. (Universidad de) Al Azhar - Ministerio de Awqaf. El Cairo, 2001.

Covián, Víctor: «Préstamo», EJE, T. XXV, Ed. Francisco Seix, Barcelona, s. f., págs. 502-549.

- «Usura», EJE, T. XXX, Ed. Francisco Seix, Barcelona, s.f. (ca. 1922), págs. 638-661.

Del ARCo ToRres, Miguel Ángel y Pons GonZález, Manuel: «Usura», en Diccionario de Derecho civil, T. II, Ed. Aranzadi, Pamplona, 1984, págs. 724-725.

ENNECCERUS, Ludwig: Derecho de obligaciones (T. II del Tratado de Derecho civil de Ludwig ENNECCERUS, Theodor KIPP y Martin WOLFF), Vol. 2. ${ }^{\circ}-1 .^{\circ}, 11 .^{a}$ ed. revis. por Heinrich LEHMANN, 2. ${ }^{a}$ ed. española, al cuidado de José Puig Brutau con anotaciones de Blas Pérez GonZález y José Alguer. Ed. Bosch. Barcelona, 1954.

EsCRICHE, Joaquín: «Interés c)», en Diccionario razonado de legislación y jurisprudencia, T. III, ed. de Juan B. Guim según la de 1874, Ed. Temis, Bogotá, 1977, págs. 152-153.

EsTASÉn, Pedro: «La ley sobre préstamos usurarios», RGLJ, T. CXIV, 1909, págs. 270-276, y T. CXVII, 1910, págs. 5-8.

FuENTESECA, Pablo: Derecho privado romano, ed. del autor. Madrid, 1978.

GómEz Royo, Enrique: El mutuo en las fuentes postclásicas bizantinas. Ed. Tirant lo Blanch. Valencia, 1992.

Herrera Bravo, Ramón: «Usurae». Problemática jurídica de los intereses en Derecho romano. Ed. Universidad de Jaén. Jaén, 1997.

INZITARI, Bruno: "Gli interessi», en La moneta (Vol. VI del Trattato di diritto commerciale e diritto pubblico dell'economia, dir. por Francesco GaLGANO), Ed. CEDAM, Padua, s. f. (1983), págs. 191-219.

- «Interessi e maggior danno», en La moneta (Vol. VI del Trattato di diritto commerciale e diritto pubblico dell'economia, dir. por Francesco GaLgano), Ed. CEDAM, Padua, s. f. (1983), págs. 221-265.

—Interessi», Digesto delle Discipline Privatistiche. Sezione civile, T. IX (Gi-Interessi), Ed. UTET, Turín, 1993, págs. 566-609. También en 
Profili del diritto delle obbligazioni, Ed. CEDAM, Padua, 2000, págs. 223-312.

- Interessi legali e maggior danno», Profili del diritto delle obbligazioni, Ed. CEDAM, Padua, 2000, págs. 105-140.

Mazzoni, Cosimo Marco: Frutti civili e interessi di capitale. Ed. Giuffrè. Milán, 1985.

PASCAL, Blaise: «Octava carta escrita a un provinciano por uno de sus amigos», en Obras. Pensamientos. Provinciales. Escritos científicos. Opúsculos y cartas, 2. ${ }^{\mathrm{a}}$ ed., pról. de José Luis ARANGUREN, trad. y notas de Carlos R. de DAMPIERRE, Ediciones Alfaguara, Madrid, 1983, págs. 126-127.

Peray March, José de: “¿Son lícitos los juicios convenidos?», RJC, T. XIV, 1908, págs. 532-534.

Pernoud, Regine: Histoire de la bourgeoisie en France. Des origines aux temps modernes. T. II. Ed. du Seuil. París, 1960.

PICcINELli, Gian Maria: "Ribā», Digesto delle Discipline Privatistiche. Sezione civile, T. XVII, Ed. UTET, Turín, 1998, págs. 495-496.

PIETTRE, Adam: Le trois âge de l'économie. Ed. Ouvrières. París, 1955.

PIRENNE, Henri: Historia económica y social de la Edad Media. 13. ${ }^{2}$ reimp. de la 1. a ed. en español. Ed. Fondo de Cultura Económica. Madrid, 1975.

Planiol, Marcel y RIPERT, Georges: Derecho civil, trad. por Leonel Pereznieto Castro. Ed. Pedagógica Iberoamericana. México, 1996.

Puig Peña, Federico: «Interés del dinero», NEJ, T. XIII, Ed. Francisco Seix, Barcelona, 1968, págs. 215-221.

Roll, Achim: «Die Höhe der Verzugszinsen», DRiZ, T. 51, 1973, págs. 339-343.

RoMANos, Ángel: «La usura», $R T$, T. XXXIX, N. ${ }^{\circ} 10,11-3-1905$, págs. 153-155.

SAEED, Abdullah: Islamic banking and interest. A study of the prohibition of Riba and its contemporary interpretation. Ed. E. J. Brill. Leiden/Nueva York/Colonia, 1996.

Santo Tomás de Aquino: Suma de Teología. T. III -Parte II-II (a)-. Biblioteca de Autores Cristianos. Madrid, 1990. 
SANTORO, Guido: «Usura», Enciclopedia forense, Vol. VII (SO-Z), Ed. Dottor Francesco Vallardi, Milán, 1962, págs. 889-892.

SimONETTo, Ernesto: Los contratos de crédito. Trad. por Juan MARTíNEZ VALENCIA y anotado por Juan V. Fuentes LoJo. Ed. J. M. ${ }^{a}$ Bosch. Barcelona, 1958. La edición original es: I contratti di credito. Ed. CEDAM. Padua, 1953.

TaRverneauX, R.: Jansenisme et prêt à intérêt. Ed. Vrin. París, 1977.

VALVERDE, Calixto: «La usura», $R T$, T. XXXIX, N. 7, 18-2-1905, págs. 97-100.

Vallés y Pujals, J.: Del préstamo a interés, de la usura y de la hipoteca. Librería Bosch. Barcelona, 1933.

VIzCARRo, C. Fernando: El préstamo usurario. Col. Nereo. Barcelona, 1963.

Sin indicación de autor: «Usura», Grande Dizionario Enciclopedico del Diritto, Vol. XXVIII (Suc-Zuc), Fratelli Fabbri Editori, Milán, 1964, págs. 298-300. 